\title{
Social Vulnerability of Oil Miners in Rural Areas
}

\author{
Vieronica Varbi Sununianti \\ Sociology Major, Faculty of Social and Political Science \\ Sriwijaya University \\ South Sumatra, Indonesia \\ vieronicavarbis@unsri.ac.ior vieronica.varbi@gmail.com
}

\begin{abstract}
This article discusses the social vulnerability of informal workers in rural areas as the implications of global economic capitalism. Globalization is abstract, but its effects are felt by traditional oil miners, whose livelihood changes due to globalization. Musi Banyuasin area, in South Sumatra, has one of the largest areas for oil and gas producers in Indonesia. However, Keban 1 village has not enjoyed the revenue of it. This article is based on qualitative research methods using data collection techniques which consists of interviews, observations, and document studies. The interview is structured and conducted on village officials, religious leaders, community leaders, traditional oil miners, and adolescents. Research validity uses data triangulation and peers de-briefing. Its findings show the social vulnerability of informal workers happens in the workers' exposure, sensitivity, and adaptive capacity which is seen from the social, economic, and environmental dimensions. Increasing economic difficulty rises along with other increasing social vulnerabilities. This paper covers vulnerability on traditional miners with high workloads and low safety precautions. The form of social vulnerability is reduced bonds of solidarity, increasing circulation of drugs and nightlife, as well as vulnerabilities towards vertical and horizontal social conflicts in mining areas. Physical environments also degradated.. For this reason, the improvement of human resources is required for the importance of education as a social elevator, assistance in training and community empowerment, as well as the strengthening of the institutional village society.
\end{abstract}

Keywords- social vulnerability; traditional oil miners; rural

\section{INTRODUCTION}

Since 2006, Indonesia had experienced an economic slump. Economic growth becomes uncertainty. One of the indicators is the low of competitiveness and investment in Indonesia. While the current market liberalization of both goods and services can not be avoided. It is important for the government to legitimize the use of part-time labor, such as labor acquired through outsourcing and contracts, to attract investment and expand job creation. It states in the Act number 13, year 2004 about Employment.

These practices according to Meulders and Wilkin [1] show the flexibility of employing labor who is adjusted with environmental changes, both in social and economic aspect. In fact, this flexibility should also cover the occupation in informal sector for example, economic activities for smallscale, unregistered, and unprotected workers.
Traditional oil miners are one of the examples of an informal sector job. These miners have become increasingly exist in some villages in Musi Banyuasin district since the year 2013. The rise of miners happened because of the declining rubber prices on a global level. Many landowners choose not to process their rubber fields, which in turn causes unemployment. Consequently, the level of crime has increased. As a result, citizens start looking for work as traditional oil miners, an occupation influenced by the existence of oil wells inherited from the Dutch colonialist period and the establishment of several large oil and gas companies operating around the area including Conoco Phillips and Medco Energy.

Traditional oil miners is an interesting subject to examine due to their various vulnerabilities. Vulnerabilities are not solely caused by workplace condition but also influenced by other social vulnerabilities, such as work process vulnerabilities, social relations vulnerabilities, economic vulnerabilities and family' life.

Musi Banyuasin district is one of Indonesia's oil and gas producers. It is known as a natural resource producing region, and $86 \%$ of the district funds depends on governmental revenue-sharing funds (Dana Bagi Hasil) [2]. However, the results have not been visible in the Keban 1 region. This article will present forms of vulnerabilities that are experienced by traditional oil miners, as well as strategies to reduce the vulnerability levels of the oil miners.

\section{THE CONCEPTUAL FRAMEWORK}

The vulnerability is related to the physical environment influences such as floods [3, 4] or droughts. It is also a multidimensional concept that includes social change, economic or political aspects. It is in line with Adger that stated: "the state of susceptibility to harm from exposure to stresses associated with environmental and social changes and from the absence of capacity to adapt" [5]. Leichenko and O'Brien state that "the extent to this is done by the environmental and economic changes influence and the capacity of regions, sectors, ecosystems, and social groups to respond to various types of natural and harmful socioeconomic shocks" [5].

This article uses three components in describing the social vulnerabilities of traditional oil miners. These three components are exposure, sensitivity, and ability to adapt [4- 
7]. The exposure level describes the essential level and to what extent socio-economic or economic failure reaches. The sensitivity level relates to the level of the system when influenced by externalities. In other words, sensitivity considers the ability of a system to respond to environmental disturbances that are formed by socio-economic and environmental situations, either directly or indirectly. The ability to adapt is the ability of the system to combine between exposure and sensitivity, so it can handle socio-economic and environmental pressure, which includes policy changes and the increasing levels of accompanying vulnerability. In this case, the ability to adapt is also related to the ability to balance the potential impacts, to take advantage of opportunities and toovercome the consequences of changes. The ability to adapt the exposure levels and sensitivity will determine the level of vulnerability.

\section{METHOD}

This article is based on the results of qualitative research methods [8-10]. The study is located in Keban 1 village, Musi Banyuasin district, South Sumatra, Indonesia. This location was selected because of changes that occurred in this region, where farmers and rubber workers shifted their livelihoods to become traditional oil miners. Furthermore, many rice fields and rubber plantations in this region switched their functions to become traditional oil mines. Data collection used structured interview guidelines, observations, and document studies. The informants in this study consist of workers in the oil mining field, village officials, community leaders, and teenagers. The validity test used triangulation data and peer de-briefing.

\section{RESULTS AND DISCUSSION}

\section{A. Description of the Location}

The characteristic of the community residing in Keban 1 village, Musi Banyuasin district, South Sumatera is patriarchy. Male community members dominate their female counterparts in both public and domestic sectors. Males are more actively involved in the community socialization process. This effects the processing of information from the community to household levels, a task that is often done by men. Sons are perceived to have economic value. It means children are expected to work as soon as possible after graduating from school to increase the family income.

The Keban 1 village consists of residents and migrants. The local population usually called "jeme Keban," are people whose families have lived in the local region for generations. Meanwhile, the newcomers are mainly migrants originating from Central Java. The difference between the populations is reflected from the segregated settlements inhabited by residents and migrants. The migrants live on river banks and work as rice farmers. Residents live on land and make their livelihood as oil miners. In addition, different locations also determine different housing structures. Residents have stilted houses because their houses are often flooded, while residents live in houses with highland structures. The differences between communities also have an impact on the political system within villages. Residents tend to have more ambition to become the village chief or village head. This causes the political choices of residents to be split, even between family members. Newcomers or migrants usually have common voices when choosing village officials. This has become a strength as well as a threat to the socio-economic life of migrants.

The global economic crisis has affected the social life of the village community. One of the impacts is the declining rubber prices in 2013. In the beginning, the local population's livelihood shifted towards becoming farmers and rubber plantation workers who got paid daily or with a revenue sharing system. Crude rubber prices fell from Rp 16.000 to Rp 4,000 (1,185 USD to 0,296 USD) per kilogram at farm levels. This situation made farmers and landowners incapable of covering production costs. Moreover, landowners needed to divide the crops to the worker ("penyadap") at rates of two thirds for local seeds or 50 percent for good seeds.

That situation triggered higher frequencies of drilling activities, refineries, and illegal oil trades in some Musi Banyuasin villages. Around $80 \%$ of Keban 1 villager switched their profession to become traditional oil miners. The oilmining activities are called "traditional" because they use a simple assembly machine, without standardization of security work nor legalization from the government. But, the community still takes up this profession due to limited job opportunities, limited level of education and skills, and a more promising income. Estimated income as oil miners can reach Rp 5.000.000 per month, disregarding side jobs. Meanwhile, public expenditures of the villages are limited because a large part of the community did not participate in governmental health insurance programs ("Badan Penjamin Jaminan Sosial”) nor free education, which meant less available leisure and relatively small food consumption.

\section{B. Social Vulnerability Traditional Oil Miners}

Traditional oil miners work in the informal sector. The condition of the workplace affects the vulnerability of the workers' social life. The vulnerability relates to social, economic and environmental aspects. The three components of social vulnerability in traditional oil miners include exposure, sensitivity, and capability to adapt.

Exposure relates to "a set of procedures in encounters with harmful socio-economic or environmental stress" [5] or the exposure level in oil miners when in contact with disturbances. Disruption of oil miners is not merely caused by their environment, but also by social, economic and political factors. Working as oil miners are very dependent on natural conditions, especially on lands that contain oil. The community uses local wisdom in searching and finding oil-laden land, searching for sounds of boiling water in the land. In addition, the work of oil miners is also dependent on the existence of interactions between groups, which include miners as investors group (materials and land), security officers, oil wells, oil picker ("pemolot"), oil collector, buyers of crude oil, cooking oil, and consumers [11]. The period of miners employment is difficult to estimate because it depends on the content of oil that is found. Meanwhile, their work condition is vulnerable to work accidents because of the lack of standardization, security, and operational permissions. 
The sensitivity relates to "the degree to which individuals or groups (as the system of interest) are affected by exposure to stress (climate or nonclimate)" [5]. Oil miners are sensitive to the impact of disturbance, directly or indirectly. Miners ability to respond to the impact of the environment is formed by their economic, social, and environmental situation. The result shows people realize the power of nature and dependency of life and nature in their work. So, the social relations between miners group is kept to minimum conflict. It is because when conflicts occur, society believes that the "womb" of oil will soon disappear itself. When the well does not produce oil, it means that the chain work will be disconnected because the amount of income is determined by the amount of oil that has successfully been drawn to the surface of the ground. For example, if "pemolot" succeeded in mining one jerry can, 500 liters can be appreciated at around Rp 500.000. Meanwhile, the quantity of oil is determined by the condition of the engine. To pursue the material that will create sufficient benefits, workers do not pay attention to the security of its work. The workers will continue to mine the oil as far as their physical condition will allow, which includes working at night and working more than 8 hours a day. Workplace safety measures are unavailable, even around oil wells. Workers still smoke without fear of fires. While workers do not have social security and health, they use doping such as drugs and alcohol to support physical stamina, releasing them from boredom and alienation.

Adaptation strategies are done by miners to respond to disturbances, to take advantage of opportunities, and to reduce vulnerability. Working as oil miners is a marginal occupation due to falling prices of rubber. But now the orientation to become oil miners is to meet family needs. Building relationships and working with some groups is an oil picker strategy to increase their income. Meanwhile, oil-mining widens the income gap between men and women. Women who help the family income as rubber harvesters are eliminated from oil-mining production. But their strategies to seek an additional financial provision for their family includes collecting oil spills around wells and opening food stalls around the location of the mine. The following is a summary of the social vulnerability of traditional oil miners.

TABLE I. COMPONENTS OF SOCIAL VULNERABILITY TRADITIONAL OIL MINERS

Vulnerability
Components

\begin{tabular}{|c|c|}
\hline $\begin{array}{l}\text { Vulnerability } \\
\text { Components }\end{array}$ & Results \\
\hline $\begin{array}{l}\text { Capacity of } \\
\text { response }\end{array}$ & $\begin{array}{l}\text { associated with oil results obtained. } \\
\text { Work accidents such as fire fall, boredom, fatigue, } \\
\text { affected production tools, polluted oil waste, cause } \\
\text { holiday workers while to recover. } \\
\text { - The workers do not get the certainty and security of } \\
\text { work, and there is no guarantee of health social and } \\
\text { legacy. } \\
\text { - Working conditions that are unsecured and claim } \\
\text { physical make some workers increase stamina } \\
\text { including with drugs consume. } \\
\text { The strategy to survive with work sideshow } \\
\text { become oil miners became the motif of working to } \\
\text { meet daily needs. } \\
\text { The strategy to take advantage of the remaining oil } \\
\text { spills are undertaken bysome miners and his } \\
\text { family. They keep collecting oil the explosives } \\
\text { statutory authority around oil wells, despite the } \\
\text { danger is greater. } \\
\text { The other strategy to increase family income with } \\
\text { open food stalls around the location of the mine. }\end{array}$ \\
\hline
\end{tabular}

\section{Social Protection Strategy for Traditional Oil Miners}

Direr economic levels become more likely along with the increasing vulnerability of social workers and family oil miners. Economic vulnerabilities force workers to undertake the work as miners. While the vulnerability of work miners covers work instability, workload and low levels of health and safety. On the other hand, the demand of work reduces bonds of solidarity, both between fellow workers and the village community. In addition, increasing the circulation of drugs, alcoholic beverages, and nightlife entertainment are a consequence of work pressure and increasing money circulation in the village.

Local governments assessment of the attractiveness of drilling illegal oil wells is a form of absorbing post-crisis rubber prices. This oil-mining has no legal basis. Even the head of South Sumatera's oil and gas stated that the authority to handle the oil-mining is located in the central government so that the local governments have no hand in it First, there is no clear legislation and special body to deal with it. So it is not surprising if some village officials, army-police, and legislative members are involved in this oil-mining business. It makes the oil-mining as an arena for interaction between seizing resources, both horizontal (between miners) and vertical (government).

For that, the government can conduct some efforts. The government (Local Government of the province, Energy and Mineral Resources and the police) needs to create the legality of cooperation with these corporations and create a clear legal umbrella to stop illegal drilling and to manage oil wells. Moreover, local communities can already process oil [13], despite being not standardized yet. The role of the government is not merely at the central level in the case of the mining laws and policies. But the role of local government is more important, especially directly relates to the vulnerability of local communities and the potential for conflict. During the discussion, we have mapped about the weak role of the State. Moreover, the role of the government is also controlled by 
corporate interests or community interests. The state is not considered able to negate the imbalance and exploitation. This condition can create social conflict in the community.

The limitations of the role of the State (government) can be strengthened by strengthening local communities (civil society through movements and community empowerment. Thus, this condition can realize a collective resistance to local social conditions. The development of the capacity for workers and oil miners can be done with the improvement of education for the children of the family and miners increasing their capacity to access the social security system, health, employment, and community empowerment. The empowerment is conducted through business management cooperations with the use of the natural potential of villages such as educational tourism, the ecological process of rubber and palm oil, mining tour, the adventure of old wells up to the location of the off-road and outbound activity. If it is possible, we could also make plantations and mining museums for future generations.

The implication of these efforts are to create social collaboration that supports each other. Significant changes are needed in the government sector, investment to the university and the community of social vulnerability oil miners. At the investment level, we need to minimize the imbalance and eliminate the impact of the mining activities. The group of investors need to pursue the legal status of its activities. The way we enhance how the organization works is by creating programs based on visions and missions that are related to the interests of the local community. At the community level, we need to change the pattern of mind and behavior (culture) on how to take advantage of the resources. Strengthening the village communities is an effective strategy to create socialeconomic vulnerability protection for miners and their family. The role of the state is very important as a source of power that is independent and objective. The role of the government, especially at the local level, is that they need to clarify the system rules of the traditional oil-mining activities concerning the local community and its natural resources. In this case, the government must be among controller groups and the miners' community, using their ability to create and implement the agreed policy and punish for violations.

\section{CONCLUSION}

Social vulnerability of traditional oil miners relates to environmental, economic, social, and political dimensions. Furthermore, the vulnerability components can be divided into exposure levels, sensitivity to disturbance, and their ability to adapt. The recommendations for future studies and assessments is that there is the need to involve government, private universities and communities to improve the quality of miners human resources and their families.

\section{ACKNOWLEDGMENT}

I would like to thank Dr. Ridhah Taqwa and Dr. Mulyanto, Sriwijaya University, Indonesia. I would also like to express my gratitude to anonymous peer reviewers for their valuable comments on this paper.

\section{REFERENCES}

[1] Tjandraningsih I and HN. The regime of flexibility and labor unions in Indonesia. Straight anal Sos 2011; 16 No. 1: 1-17.

[2] Sununianti VV. The labor market is flexible and social exclusion in higher education (a study of educators apprentice working conditions in FISIP UI after the scheme educators UI). Indonesia, 2012.

[3] Sununianti VV. The regime of flexibility and government institutions: the comparative studies of the labor market flexible at the University and Banking. Palembang-Indonesia, 2014.

[4] Bahruddin. Hidup pasca berkelimpahan. Kompas, 2016, p. 6.

[5] Rufat S, include E, Burton CG, et al. International Journal of Disaster Risk Reduction of Social vulnerability to floods : Review of case studies and implications for chaired the. Int $J$ Disaster Risk Reduct 2015; 14: 470-486.

[6] Sariffudin, Astuti KD, Farhaeni, Gustika A, et al. Vulnerability assessment : the role of coastal informal settlement growth to social vulnerability in Genuk district sub-district, Semarang city. In: 2 nd International Conference on Tropical and Coastal Anti Aging society has been Eco Development. IOP Publishing, 2016. Epub ahead of print 2016. DOI: 10.1088/1742-6596/755/1/011001.

[7] Nazari S, Sedighi Pezeshki G, H, et al. Vulnerability of wheat farmers' : toward a conceptual framework. Indic Ecol 2015; 52: 517-532.

[8] Gallopin GC. Linkages between vulnerability, resilience, and adaptive capacity. Glob Environ Chang 2006; 16: 293-303.

[9] Morzaria-luna HN, Turk-Boyer P, Moreno-baez M. Social indicators of vulnerability for fishing communities in the Northern Gulf of California, Mexico : Implications for climate change. Mar Policy 2014; 45: 182-193.

[10] Bogdan R and SJT. The basics of qualitative research (terj.). Surabaya: National Business, 1993.

[11] Neuman CLS. Basic of social research: qualitative and quantitative Approaches. 2 nd. Pearson Education, 2007.

[12] Creswell JW. Research design qualitative, quantitative and mixed methods approaches. 2 nd Ed. New Delhi : Sage Publications, 2003.

[13] Sununianti VV. Labor and sustainable development in traditional oil-mining. In: 1st International Geography Seminar 2017. Bandung: in press, 2017. 